\title{
Comparative proximate composition of selected edible vegetables harvested from farmland nearby oil impacted sites in Rivers state, Nigeria
}

\author{
Igwe, K. $\mathrm{O}^{1}$., Onyeike, E. $\mathrm{N}^{2}$., Uwakwe, A. $\mathrm{A}^{2}$ \\ ${ }^{1}$ Department of Biochemistry, Federal University of Technology, Owerri, Nigeria \\ ${ }^{2}$ Department of Biochemistry, University of Port Harcourt, Port Harcourt, Nigeria
}

\begin{abstract}
Comparative proximate composition of selected edible vegetables (Hibiscus esculentus, Telfairia occidentalis, vernonia amygdalina and Talinum triangulare) harvested in farmland nearby oil impacted sites in Rivers State (Bomu, Eleme, Umusoya, Rukpokwu and Omagwa) were investigated. The results obtained were compared to the proximate composition of similar edible vegetables harvested from non oil producing areas in Imo State. The was a significantly higher moisture levels in Hibiscus esculentus, Talinum triangulare and Telfairia occidentalis harvested from all the study areas (Highest value in Hibiscus esculentus harvested from Eleme: $6.26 \pm 0.03$ and lowest value in Telfairia occidentalis harvested from Bomu: $4.04 \pm 0.02$ ). All the vegetables harvested from the study areas were significantly lower in ash when compared to vegetables from the control areas (Highest value in Hibiscus esculentus harvested from Rukpokwu: $13.51 \pm 0.04$ and lowest value in Telfairia occidentalis harvested from Rukpokwu: $9.11 \pm 0.01)$. The crude protein content of vegetables indicated significantly lower value for all the vegetables harvested from the study areas (Highest value in Telfairia occidentalis harvested from Omagwa: $16.51 \pm 0.01$ and lowest value in Talinum triangulare harvested from Umusoya, Bomu and Eleme: $8.12 \pm 0.02)$. All vegetables harvested from the study areas were significantly higher in crude fat when compared to vegetables from the control areas (Highest value in Talinum triangulare harvested from Rukpokwu and Omagwa: $4.12 \pm 0.01$ and lowest value in Hibiscus esculentus harvested from Воти: $2.06 \pm 0.02)$, total carbohydrate and calorific value while the result for fibre was of significant higher value for all vegetable samples harvested from the studied areas. Values obtained indicated vegetables with lower quality in the study areas.
\end{abstract}

Keywords: Edible vegetables, Proximate Composition, oil spill, farmland.

\section{INTRODUCTION}

The seashores and land areas of the Niger Delta in Nigeria have witnessed large scaled oil exploration and exploitations over the years. (Nwilo and Badejo, 2005). River state, a major state in the Niger Delta is crisscrossed by thousands of kilometres of pipelines, punctuated by wells and flow stations. Poor maintenance of oil infrastructure equipment, sabotage of oil infrastructures, theft of oil and illegal refining all contribute to rampant oil spillages in the `area (Annon, 2006)

After spillage, petroleum components undergo various physical and chemical changes such as evaporation, biodegradation and photo oxidation. These changes help the removal of the hydrocarbon molecules from the point of spillage (Douglas et al., 1996; Garrett et al, 1998). The weathering process results in the formation of less complex hydrocarbon. If the process is complete, the remaining waste or by- product are mainly carbon dioxide, water, fatty acid and paraffin. However this is not to be as the processes are very slow to bring about these non- toxic and immobile hydrocarbons (Apajalahti and Salkinoja-solonen, 1986). This process may be so slow that hydrocarbons and associated pollutants may remain in soils and groundwater for decades, enough time for it to be runoff into nearby arable land.

Crude oil and its refined petroleum products is known to contain several toxic organic and inorganic components such as polycyclic aromatic hydrocarbons, atoms of sulphur, nitrogen, oxygen as well as metals such as iron, vanadium, sodium, nickel, chromium and other metals present in small amounts (Irwin et al., 1998) which constitutes a significant risk to plants, people and organisms. 
The effects of oil pollutants on edible vegetables vary according to the type and amount of pollutants involved. Crude oil is phytotoxic because it creates unsatisfactory conditions for plant growth ranging from heavy metal toxicity to inhibited aeration of the soil. Crude oil spills affect vegetables adversely by creating conditions which make nutrients like nitrogen and oxygen needed for growth unavailable to them (Ogbo et al., 2009). It has also been reported that plants and soil microbes compete for the little nutrient available in soils that are not rich like that polluted with crude oil thereby suppressing the growth of plants in such soils.

The penetration of high doses of petroleum pollutants in the cells of the edible vegetables may also lead to significant deviation from the norm and some cases, even to the complete cell destruction and plant death (Korte, et al., 2000).

Cells of the vegetables exposed to significant quantity of these toxicants will be subjected to oxidative stress, which will then rely on protective usage of its anti oxidant molecules such as tocopherol (vitamin E) and ascorbic acid (Vitamin C) (Naidu, 2013). This may result in alteration of nutrient composition of such vegetables. Petroleum contaminants may also increase the concentration of hydrocarbon in the soil and still lead to the predominance of organic carbon over the content of nitrogen in the humus horizon, which may result to large supply of energy and proportionately decrease on the availability of nitrogen (Ziolkowskai and Wyskowskii, 2010).

Harmful effect of oil spill pollutants on edible vegetables vary from lethal to sub lethal effects caused by either the physical nature of the pollutants or by its inherently toxic chemicals components. (Oyinloye and Olamiju, 2013). The competition for nitrogen between microorganisms that are degrading the hydrocarbons and the plant root systems may result to acute shortage of nitrogen for plants. This may inhibit the plant growth and decrease plant protein content or slight increase in carbohydrate content. Direct effect of petroleum pollutants may be by formation of oily films in leaves of the vegetables; this reduces transpiration and respiration rates. The entire process can cause changes in the metabolic processes, which may result in some modification in the chemical compositions of the vegetables (Ziolkowskai and Wyskowskii, 2010).

The present study was undertaken to assess the comparative proximate composition of selected edible vegetables harvested from farmland nearby oil impacted sites in Rivers State.

\section{Materials ANd Methods}

\subsection{Vegetable Samples Collection}

Four vegetables Abelmoschus esculentus,(Okra) Telfairia occidentalis (pumpkin) vernonia amygdalina (Bitter Leaf)and Talinum triangulare (Water Leaf) were collected from farmland around oil spilled sites in five communites of Rivers State viz Umusoya, Eleme, Omagwa, Rukpowu, and Bomu while same vegetables from five non oil producing communities in Imo State viz Owerri, Mgbidi, Mbano, Mbaise, and Orlu were used as control.

\subsection{Collection and Preparation of Vegetable Samples}

The harvested vegetables were sorted to remove extraneous materials, spoilt and unhealthy ones. The sorted vegetables were washed with distilled water. The samples were sliced into small bits with the aid of a knife (this is done to increase the surface area of the sample) and it was then oven dried, macerated, sieved and properly stored.

\subsection{Evaluation of Proximate Composition}

The methods described by James (1995) and Onwuka (2005) were used to determine Crude fibre. Fat content was determined by the methods of Min and Boft (2003). Moisture was determined by the method of AOAC (1990). The sample's total protein content was determined by microkjeldhal described by James (1995). Protein concentration was obtained by determining total nitrogen and multiplying by the factor -6.25 . Carbohydrate content was calculated using the arithmetical difference described by Pearson (1976) and James (1995). 
Comparative proximate composition of selected edible vegetables harvested from farmland nearby oil impacted sites in Rivers state, Nigeria

\section{RESULT}

Table1. Proximate composition (\%) of Hibiscus esculentus harvested from the areas investigated.

\begin{tabular}{|l|l|l|l|l|l|l|l|}
\hline Location & Moisture & Ash & $\begin{array}{l}\text { Crude } \\
\text { protein }\end{array}$ & Crude fat & Fibre & $\begin{array}{l}\text { Total } \\
\text { carbohydrate }\end{array}$ & $\begin{array}{l}\text { Calorific value } \\
\text { Kcal/100g } \\
\text { sample }\end{array}$ \\
\hline UMUSOYA & $5.86 \pm$ & $\begin{array}{l}13.09 \pm \\
0.01^{\mathrm{a}}\end{array}$ & $\begin{array}{l}8.65 \pm \\
0.05^{\mathrm{a}}\end{array}$ & $\begin{array}{l}2.17 \pm \\
0.01^{\mathrm{a}}\end{array}$ & $\begin{array}{l}9.56 \pm \\
0.05^{\mathrm{a}}\end{array}$ & $\begin{array}{l}60.66 \pm \\
0.09^{\mathrm{a}}\end{array}$ & $296.79 \pm 0.24^{\mathrm{a}}$ \\
& $0.05^{\mathrm{b}}$ & $13.51 \pm$ & $8.62 \pm$ & $2.08 \pm$ & $9.32 \pm$ & $61.44 \pm$ & $298.98 \pm 0.35^{\mathrm{b}}$ \\
& $0.03^{\mathrm{a}} \pm$ & $0.04^{\mathrm{c}}$ & $0.10^{\mathrm{ab}}$ & $0.03^{\mathrm{b}}$ & $0.04^{\mathrm{c}}$ & $0.14^{\mathrm{a}}$ & \\
\hline RUKPOKWU & $0.02^{\mathrm{c}}$ & $13.11 \pm$ & $8.68 \pm$ & $2.14 \pm$ & $9.49 \pm$ & $60.42 \pm$ & $295.69 \pm 0.14^{\mathrm{c}}$ \\
& $0.16 \pm$ & $0.02^{\mathrm{ab}}$ & $0.02^{\mathrm{abc}}$ & $0.02^{\mathrm{abc}}$ & $0.02^{\mathrm{ab}}$ & $0.02^{\mathrm{ab}}$ & \\
\hline BMAGWA & $0.02^{\mathrm{a}}$ & $13.22 \pm$ & $8.31 \pm$ & $2.06 \pm$ & $8.59 \pm$ & $61.72 \pm$ & $298.66 \pm 0.30^{\mathrm{b}}$ \\
& $0.10 \pm$ & $0.02^{\mathrm{d}}$ & $0.03^{\mathrm{d}}$ & $0.02^{\mathrm{b}}$ & $0.05^{\mathrm{d}}$ & $0.05^{\mathrm{c}}$ & \\
\hline ELEME & $6.26 \pm$ & $13.12 \pm$ & $8.64 \pm$ & $2.17 \pm$ & $9.56 \pm$ & $60.24 \pm$ & $295.09 \pm 0.12^{\mathrm{d}}$ \\
& $0.03^{\mathrm{d}}$ & $0.03^{\mathrm{ab}}$ & $0.04^{\mathrm{abc}}$ & $0.01^{\mathrm{ac}}$ & $0.04^{\mathrm{ab}}$ & $0.07^{\mathrm{ab}}$ & \\
\hline CONTROL & $4.18 \pm$ & $16.45 \pm$ & $11.16 \pm$ & $1.09 \pm$ & 11.09 & $55.05 \pm$ & $274.59 \pm 0.34^{\mathrm{e}}$ \\
AREA & $0.00^{\mathrm{e}}$ & $0.01^{\mathrm{e}}$ & $0.99^{\mathrm{e}}$ & $0.01^{\mathrm{d}}$ & $\pm 0.01^{\mathrm{e}}$ & $0.02^{\mathrm{d}}$ & \\
\hline
\end{tabular}

Values are Means \pm standard deviations of triplicate determinations.

Values in each column with different superscript letters differ significantly at 5\% level $(p<0.05)$.

Table2. Proximate composition (\%) of Telfairia occidentalis harvested from the areas investigated

\begin{tabular}{|l|l|l|l|l|l|l|l|}
\hline Location & Moisture & Ash & $\begin{array}{l}\text { Crude } \\
\text { protein }\end{array}$ & Crude fat & Fibre & $\begin{array}{l}\text { Total } \\
\text { carbohydrate }\end{array}$ & $\begin{array}{l}\text { Calorific } \\
\text { value } \\
\text { Kcal/100g } \\
\text { sample }\end{array}$ \\
\hline UMUSOYA & $\begin{array}{l}4.06 \pm \\
0.01^{\mathrm{a}}\end{array}$ & $\begin{array}{l}9.17 \pm \\
0.03^{\mathrm{a}}\end{array}$ & $\begin{array}{l}16.32 \pm \\
0.02^{\mathrm{a}}\end{array}$ & $\begin{array}{l}3.99 \pm \\
0.01^{\mathrm{a}}\end{array}$ & $\begin{array}{l}12.17 \pm \\
0.02^{\mathrm{a}}\end{array}$ & $\begin{array}{l}54.30 \pm \\
0.04^{\mathrm{a}}\end{array}$ & $\begin{array}{l}318.35 \pm \\
0.21^{\mathrm{a}}\end{array}$ \\
\hline RUKPOKWU & $4.10 \pm$ & $9.11 \pm$ & $16.21 \pm$ & $4.01 \pm$ & $12.02 \pm$ & $54.54 \pm$ & 319.10 \\
& $0.02^{\mathrm{b}}$ & $0.01^{\mathrm{a}}$ & $0.01^{\mathrm{b}}$ & $0.01^{\mathrm{ab}}$ & $0.02^{\mathrm{c}}$ & $0.03^{\mathrm{b}}$ & $\pm 0.11^{\mathrm{ab}}$ \\
\hline OMAGWA & $4.30 \pm$ & $9.80 \pm$ & $16.51 \pm$ & $4.11 \pm$ & $12.25 \pm$ & $53.03 \pm$ & 315.18 \\
& $0.01^{\mathrm{c}}$ & $0.01^{\mathrm{c}}$ & $0.01^{\mathrm{d}}$ & $0.01^{\mathrm{c}}$ & $0.03^{\mathrm{d}}$ & $0.03^{\mathrm{c}}$ & \pm 0.19 \\
\hline BOMU & $4.04 \pm$ & $9.19 \pm$ & $16.24 \pm$ & $3.91 \pm$ & $12.12 \pm$ & $54.51 \pm$ & $318.77 \pm$ \\
& $0.02^{\mathrm{a}}$ & $0.02^{\mathrm{ab}}$ & $0.02^{\mathrm{bc}}$ & $0.05^{\mathrm{ab}}$ & $0.01^{\mathrm{b}}$ & $0.09^{\mathrm{b}}$ & $0.96^{\mathrm{abc}}$ \\
\hline ELEME & $4.11 \pm$ & $9.16 \pm$ & $16.29 \pm$ & $4.01 \pm$ & $12.16 \pm$ & $54.27 \pm$ & $318.33 \pm$ \\
& $0.01^{\mathrm{b}}$ & $0.01^{\mathrm{ab}}$ & $0.02^{\mathrm{ac}}$ & $0.01^{\mathrm{ab}}$ & $0.03^{\mathrm{ab}}$ & $0.03^{\mathrm{a}}$ & $0.12^{\mathrm{abc}}$ \\
\hline CONTROL & $3.27 \pm$ & $11.73 \pm$ & $17.36 \pm$ & $1.00 \pm$ & $13.47 \pm$ & $53.19 \pm$ & $219.15 \pm$ \\
AREA & $0.01^{\mathrm{d}}$ & $0.01^{\mathrm{d}}$ & $0.01^{\mathrm{e}}$ & $0.01^{\mathrm{d}}$ & $0.01^{\mathrm{e}}$ & $0.02^{\mathrm{d}}$ & $0.04^{\mathrm{d}}$ \\
\hline
\end{tabular}

Values are Means \pm standard deviations of triplicate determinations.

Values in each column with different superscript letters differ significantly at $5 \%$ level $(p<0.05)$.

Table3. Proximate composition (\%) Vernonia amygdalina harvested from the areas investigated

\begin{tabular}{|l|l|l|l|l|l|l|l|}
\hline Location & Moisture & Ash & $\begin{array}{l}\text { Crude } \\
\text { protein }\end{array}$ & Crude fat & Fibre & $\begin{array}{l}\text { Total } \\
\text { carbohydrate }\end{array}$ & $\begin{array}{l}\text { Calorific } \\
\text { value } \\
\text { Kcal/100g } \\
\text { sample }\end{array}$ \\
\hline UMUSOYA & $4.07 \pm$ & $\begin{array}{l}10.30 \pm \\
0.05^{\mathrm{a}}\end{array}$ & $\begin{array}{l}10.68 \pm \\
0.08^{\mathrm{a}}\end{array}$ & $\begin{array}{l}2.25 \pm \\
0.03^{\mathrm{a}}\end{array}$ & $\begin{array}{l}10.20 \pm \\
0.03^{\mathrm{a}}\end{array}$ & $\begin{array}{l}62.50 \pm \\
0.18^{\mathrm{abc}}\end{array}$ & $\begin{array}{l}312.92 \\
\pm 0.28^{\mathrm{ab}}\end{array}$ \\
& $0.03^{\mathrm{a}}$ & $10.34 \pm$ & $10.71 \pm$ & $2.23 \pm$ & $10.22 \pm$ & $62.41 \pm$ & $312.56 \pm$ \\
& $4.09 \pm$ & $0.03^{\mathrm{ab}}$ & $0.04^{\mathrm{ab}}$ & $0.03^{\mathrm{ab}}$ & $0.02^{\mathrm{ab}}$ & $0.13^{\mathrm{abc}}$ & $0.13^{\mathrm{abcde}}$ \\
\hline RUKPOKWU & $0.03^{\mathrm{ab}}$ & $10.36 \pm$ & $10.73 \pm$ & $2.25 \pm$ & $10.22 \pm$ & $62.32 \pm$ & 312.49 \\
& $4.11 \pm$ & $0.03^{\mathrm{abc}}$ & $0.04^{\mathrm{abc}}$ & $0.02^{\mathrm{abc}}$ & $0.02^{\mathrm{abc}}$ & $0.09^{\mathrm{abc}}$ & $\pm 0.17^{\mathrm{bcde}}$ \\
\hline BOMGWA & $0.01^{\mathrm{abc}}$ & $10.35 \pm$ & $10.70 \pm$ & $2.23 \pm$ & $7.03 \pm$ & $62.39 \pm$ & $312.47 \pm$ \\
& $0.01^{\mathrm{abcd}}$ & $0.02^{\mathrm{abcd}}$ & $0.05^{\mathrm{abcd}}$ & $0.03^{\mathrm{abcd}}$ & $4.39^{\mathrm{abcd}}$ & $0.12^{\mathrm{abc}}$ & $0.04^{\text {bcde }}$ \\
\hline ELEME & $4.11 \pm$ & $10.36 \pm$ & $10.74 \pm$ & $2.25 \pm$ & $10.24 \pm$ & $62.30 \pm$ & $312.37 \pm$ \\
& $0.01^{\mathrm{abcde}}$ & $0.03^{\mathrm{abcd}}$ & $0.03^{\mathrm{abcd}}$ & $0.02^{\mathrm{abcd}}$ & $0.01^{\mathrm{abcd}}$ & $0.08^{\mathrm{abc}}$ & $0.16^{\mathrm{bcde}}$ \\
\hline CONTROL & $4.12 \pm$ & $16.90 \pm$ & $13.83 \pm$ & $2.17 \pm$ & $10.70 \pm$ & $52.29 \pm$ & 283.97 \\
AREA & $0.01^{\mathrm{abce}}$ & $0.01^{\mathrm{e}}$ & $0.01^{\mathrm{e}}$ & $0.01^{\mathrm{e}}$ & $0.01^{\mathrm{e}}$ & $0.02^{\mathrm{d}}$ & $\pm 0.06^{\mathrm{f}}$ \\
\hline
\end{tabular}

Values are Means \pm standard deviations of triplicate determinations.

Values in each column with different superscript letters differ significantly at 5\% level $(p<0.05)$. 
Igwe, K. O et al.

Table4. Proximate composition (\%) of Talinum triangulare harvested from the areas investigated

\begin{tabular}{|c|c|c|c|c|c|c|c|}
\hline Location & Moisture & Ash & $\begin{array}{l}\text { Crude } \\
\text { protein }\end{array}$ & Crude fat & Fibre & $\begin{array}{l}\text { Total } \\
\text { carbohydrate }\end{array}$ & $\begin{array}{l}\text { Calorific } \\
\text { value } \\
\text { Kcal/100g } \\
\text { sample }\end{array}$ \\
\hline UMUSOYA & $\begin{array}{l}5.22 \pm \\
0.03^{\mathrm{a}}\end{array}$ & $\begin{array}{l}12.10 \pm \\
0.02^{\mathrm{a}}\end{array}$ & $\begin{array}{l}8.12 \pm \\
0.02^{\mathrm{a}}\end{array}$ & $\begin{array}{l}4.10 \pm \\
0.02^{\mathrm{a}}\end{array}$ & $\begin{array}{l}10.61 \pm \\
0.03^{\mathrm{abc}}\end{array}$ & $\begin{array}{l}59.85 \pm \\
0.09^{\text {abcd }}\end{array}$ & $\begin{array}{l}308.79 \pm \\
0.18^{\text {abcd }}\end{array}$ \\
\hline RUKPOKWU & $\begin{array}{l}5.25 \pm \\
0.02^{\mathrm{ab}}\end{array}$ & $\begin{array}{l}12.12 \pm \\
0.02^{\mathrm{ab}}\end{array}$ & $\begin{array}{l}8.13 \pm \\
0.01^{\mathrm{ab}}\end{array}$ & $\begin{array}{l}4.12 \pm \\
0.01^{\mathrm{ab}}\end{array}$ & $\begin{array}{l}10.60 \pm \\
0.03^{\mathrm{abc}}\end{array}$ & $\begin{array}{l}59.78 \pm \\
0.06^{\text {abcd }}\end{array}$ & $\begin{array}{l}306.32 \pm \\
5.55^{\text {abcd }}\end{array}$ \\
\hline OMAGWA & $\begin{array}{l}5.21 \pm \\
0.04^{\mathrm{abc}}\end{array}$ & $\begin{array}{l}12.11 \pm \\
0.01^{\mathrm{abc}}\end{array}$ & $\begin{array}{l}8.14 \pm \\
0.01^{\mathrm{abc}}\end{array}$ & $\begin{array}{l}4.12 \pm \\
0.01^{\mathrm{abc}}\end{array}$ & $\begin{array}{l}10.61 \pm \\
0.03^{\mathrm{abc}}\end{array}$ & $\begin{array}{l}59.81 \pm \\
0.08^{\text {abcd }}\end{array}$ & $\begin{array}{l}308.86 \pm \\
0.30^{\text {abcd }}\end{array}$ \\
\hline BOMU & $\begin{array}{l}5.22 \pm \\
0.03^{\mathrm{abcd}}\end{array}$ & $\begin{array}{l}12.09 \pm \\
0.03^{\mathrm{abd}}\end{array}$ & $\begin{array}{l}8.12 \pm \\
0.02^{\text {abcd }}\end{array}$ & $\begin{array}{l}4.10 \pm \\
0.02^{\mathrm{abcd}}\end{array}$ & $\begin{array}{l}10.61 \pm \\
0.03^{\text {abcd }}\end{array}$ & $\begin{array}{l}59.87 \pm \\
0.09^{\text {abcd }}\end{array}$ & $\begin{array}{l}308.81 \\
\pm 0.26^{\text {abcd }} \\
\end{array}$ \\
\hline ELEME & $\begin{array}{l}5.18 \pm \\
0.08^{\mathrm{abcd}}\end{array}$ & $\begin{array}{l}12.11 \pm \\
0.02^{\text {abcd }}\end{array}$ & $\begin{array}{l}8.12 \pm \\
0.02^{\mathrm{abcd}}\end{array}$ & $\begin{array}{l}4.10 \pm \\
0.02^{\mathrm{abcd}}\end{array}$ & $\begin{array}{l}10.59 \pm \\
0.07^{\text {abcd }}\end{array}$ & $\begin{array}{l}59.91 \pm \\
0.17^{\text {abcd }}\end{array}$ & $\begin{array}{l}309.02 \pm 0.46^{\mathrm{a}} \\
\text { bcd }\end{array}$ \\
\hline $\begin{array}{l}\text { CONTROL } \\
\text { AREA }\end{array}$ & $\begin{array}{l}4.36 \pm \\
0.01^{\mathrm{e}}\end{array}$ & $\begin{array}{l}19.39 \pm \\
0.01^{\mathrm{e}}\end{array}$ & $\begin{array}{l}9.80 \pm \\
0.01^{\mathrm{e}}\end{array}$ & $\begin{array}{l}2.13 \pm \\
0.01^{\mathrm{e}}\end{array}$ & $\begin{array}{l}11.36 \pm \\
0.01^{\mathrm{e}}\end{array}$ & $\begin{array}{l}50.98 \pm \\
0.02^{\mathrm{e}}\end{array}$ & $\begin{array}{l}269.22 \pm \\
0.04^{\mathrm{e}}\end{array}$ \\
\hline
\end{tabular}

Values are Means \pm standard deviations of triplicate determinations.

Values in each column with different superscript letters differ significantly at $5 \%$ level $(p<0.05)$.

The results of percentage proximate composition of edible vegetables from farmlands within the areas studied are presented in Tables $1-4$.

The results of percentage proximate composition of Hibiscus esculentus is presented in Table 1. Hibiscus esculentus harvested from the control area had a significantly lower $(\mathrm{p}<0.05)$ value in crude fat, total carbohydrate and calorific value $(1.09 \pm 0.01 \%, 55.05 \pm 0.02 \%$ and $274.59 \pm 0.34 \%$ respectively) while it had significantly higher $(\mathrm{p}<0.05)$ value in ash, crude protein and fibre $(16.45 \pm$ $0.01 \%, 11.16 \pm 0.99 \%$ and $11.09 \%$ respectively) when compared to those harvested from other areas. Hibiscus esculentus harvested from Rukpokwu had a significantly lower $(\mathrm{p}<0.05)$ value $(5.03 \pm$ $0.02 \%$ ) in moisture when compared to those harvested from other areas, this value was however followed by the moisture content of Hibiscus esculentus harvested from the control area.

The percentage proximate composition of Telfairia occidentalis is shown in Table 2. Telfairia occidentalis harvested from the control area had a siginificantly lower $(\mathrm{p}<0.05)$ value in moisture, crude fat, and calorific value $(3.27 \pm 0.01 \%, 1.00 \pm 0.01 \%$ and $219.15 \pm 0.04 \%$ respectively) while it had significantly higher $(\mathrm{p}<0.05)$ value in ash, crude protein and fibre $(11.73 \pm 0.01 \%, 17.36 \pm 0.01 \%$ and $13.47 \pm 0.01 \%$ respectively) when compared to those harvested from other areas. Telfairia occidentalis harvested from Omagwa had a significantly lower $(\mathrm{p}<0.05)$ value $(53.03 \pm 0.03 \%)$ in total carbohydrate when compared to those harvested from other areas, this value was however followed by total carbohydrate content of Telfairia occidentalis harvested from the control area.

Table 3. Presents the result of percentage proximate composition of Vernonia amygdalina. Vernonia amygdalina harvested from the control area had a siginificantly lower $(\mathrm{p}<0.05)$ value in crude fat and calorific value $(2.17 \pm 0.01 \%$, and $283.97 \pm 0.06 \%$ respectively) while it had significantly higher $(\mathrm{p}<0.05)$ value in ash, crude protein and fibre $(16.90 \pm 0.01 \%, 13.83 \pm 0.01 \%$ and $10.70 \pm 0.01 \%$ respectively) when compared to those harvested from other areas. Vernonia amygdalina harvested from Umusoya had the lowest value $(4.07 \pm 0.03)$ in total moisture when compared to those harvested from other areas, this value was followed by moisture content of Vernonia amygdalina harvested from Rukpokwu and then Bomu. Vernonia amygdalina harvested from Umusoya, Omagwa and Eleme had the highest values in crude fat when compared to those harvested from other areas, this value were not however statistically significant.

The percentage proximate composition of Talinum triangulare is given in Table 4. Talinum triangulare harvested from the control area had a significantly lower $(\mathrm{p}<0.05)$ value in crude fat, total carbohydrate and calorific value $(2.13 \pm 0.01 \%, 50.98 \pm 0.02 \%$ and $269.22 \pm 0.04 \%$ respectively) while it had significantly higher $(\mathrm{p}<0.05)$ value in moisture, ash, crude protein and fibre $(6.36 \pm$ $0.01 \%, 19.39 \pm 0.01 \% 9.80 \pm 0.01 \%$ and $11.36 \pm 0.01 \%$ respectively) when compared to those harvested from other areas. 


\section{DISCUSSION}

The result for proximate analysis indicated that the percentage moisture was significantly higher in Hibiscus esculentus and Telfairia occidentalis harvested from the study areas. The high moisture contents of these selected vegetables suggest that these vegetables cannot be stored for long because of high water activity. When the moisture content of vegetable is high, it maintains the protoplasm of the vegetable. (Gbadamosi et al, 2011). High moisture content maintains the activity of water-soluble enzymes necessary for metabolism in the vegetables (Ihenacho and ubebani 2009). High moisture content however causes difficulty in maintaining quality of food items as the samples are prone to microbial deterioration while being stored. (Onyeike et al., 2003); microorganisms that results to spoilage survive in foods with high moisture content (Emebu et al, 2011).

The significantly higher $(\mathrm{p}>0.05)$ ash level in all studied vegetables from the control area as compared to values from the study area may be as a result of crude oil contamination of the soils with petroleum hydrocarbon. The elevated ash level of samples from control area can be due to increased amount of available mineral in the soil as against soil from crude oil polluted farmlands in the study areas. Due to crude oil contamination in the soil, mineral elements are no longer usable by the roots of these crops. As assimilation of nutrients is done through plant roots; crops grown in uncontaminated soil may accumulate relevant minerals in their organs causing a rise in ash level. Vegetables are known to bioaccumulate high concentration of minerals from uncontaminated soil than from contaminated soil. (Cobb et al.,2000).

The protein levels of vegetables harvested from the control area were significantly higher when compared to those from the study areas probably because of favourable soil nutrient. It was previously reported that Imo state soil is high in nitrate (Ezeonu et al., 1994). Also the reduced protein level in the study areas may be because of oxidative stress induced by toxicants from petroleum products. Oxidative stress can influence protein synthesis or initiates a rise in protein oxidation and possible destruction of plant cells. The result of this study agrees with that of Nwaogu and Onyeze (2010), in their work with puccinellia maritama that plant cell membranes are destroyed by crude oil pollution and thus affecting ribosome which is a site of protein synthesis.

The significantly higher ( $\mathrm{p}>0.05$ ) value in lipid level of Hibiscus esculentus and Telfairia occidentalis harvested from the study areas can be attributed to the capability of these crops to assimilate and bioaccumulate crude oil in their tissues. This is also in agreement with study done by Ziolkowskai and Wyszkowskaii (2010) which reported that pollution of soil with petroleum toxicants may not only reduce the development of crops but can lead to accumulation of hydrocarbon within plant tissues. Crude oil pollution may also exhibits a direct influence by production of oily films on crops, thereby lowering transpiration and respiration rates in crops which ultimately lead to alteration in the chemical compositions of crops (Ziolkowskai and Wyszkowskaii 2010). The results also indicated that Hibiscus esculentus and Telfairia occidentalis harvested from the control area were significantly higher ( $>0.05$ ) in crude fibre level than those from the study areas. This may suggests that crude oil contamination influences the crude fibre levels of these vegetables by producing a decrease in crude fibre level. Fibre in crops have various functions in the human body, it is said to have a cleansing effect on the GIT by eradicating potential carcinogens from the body while blood sugar levels under normal range (Emebu, 2011).

Carbohydrate levels are generally high in all the vegetable samples irrespective of location. Hibiscus esculentus and Telfairia occidentalis harvested from the study areas were significantly higher ( $>0.05)$ in carbohydrate than those harvested from farmlands in the control areas. The high level of carbohydrate in the selected vegetables from both locations is an indication that they contribute effectively to the energy content of the food items.

This study has shown that Abelmoschus esculentus,Telfairia occidentalis vernonia amygdalina and Talinum triangulare are good sources of nutrients and should be consumed. Also, runoff from oil impacted sites showed negative effect on these vegetables by reducing their qualities. Local farmers around oil impacted communities should be enlightened on the inherent dangers of cultivating these vegetables when oil spills. Oil companies should be compelled not to limit remediation effort within the spilled sites but to extend it to arable soil around the spilled sites. 


\section{REFERENCES}

Annon (2006). Niger Delta Natural Resource Damage Assessment and Restoration Project. Phase 1Scoping Report. Federal ministry of Environment, Abuja Nigeria Conservation Foundation, Lagos, WWF UK, CEESP-IUCN Commission on Environment, Economic and Social Policy

AOAC (1990). Method of analyses of association of official analytical chemists. Journal of association of analytical chemists. 25:516 - 524

Apajalahti, J.A. and Salkinoja- Salonen, M.S. (1986). Degradation of polychlorinated phenols by rhodococcus chiorophenolicus .Applied microbiology and Biotechnology 25, 62-67

Cobb, G.P, Sand, S.K, Waters, M, Wixson, B.G, and Dorwars, K.E. (2000) Accumulation of heavy metals by vegetables grown in mine wastes. Environ Toxical chem. 19:600-607

Douglas, G.S., Bence, A.E., Prince, R.c., Mcmillen, S.J., Butler, E.L. (1996). Environmental Stability of Selected Petroleum Hydrocarbon Source and Weathering ratios. Environ.Sci. Technol.,30, 2332

Emebu, P. K.; Anyika, J. U. (2011) Proximate and mineral composition of Kale (Brassica oleracea) grown in Delta State, Nigeria. Pak. J. Nutr., 10: 190-194.

Ezeonu, F.C.,Egboka, B. C. E and Aze, S. S. (1994). Ferlilizer applications, nitrate loading patterns, water resources quality and their ecotoxicological implications in Awka area of Nigeria. Environ.Toxicol.Water Qual., 9: 141-144

Garrett, R. M., Pickering, I. J., Haith, C. E., Prince, R. C. (1998). Photooxidation of crude oils. Environ. Sci. Techonol., 32, 3719.

Gbadamosi, I.T.; Moody, J.O.; Lawal, A.M. (2011) Phytochemical screening and proximate analysis of eight ehnobotanicals used as antimalaria remedies in Ibadan, Nigeria. J. Appl. Biosci., 44: 2967-2971.

Ihenacho, K.; Ubebani, A.C (2009). Nutritional composition of some leafy vegetables consumed in Imo State, Nigeria. J. Appl. Sci. Environ. Manag., 13: 35-38.

Irwin, R.J., Van mouwerik, M.V., stevens, lynette, (1998). Environmental contaminants encyclopedia.

James C. S. (1995). Analytical chemistry of foods. Backie Academic Journal 198: 125 - 181

Korte, F., Kvesitadze, G., Ugrekhelidze, D.,Gordeziani, M., Khatisashuili, G., Buadze, O., ZaalisIwili, G. and Coulston, F. (2000). J. Ecotoxicol. Environ. Safety.,47 (1):1-26.

Naidu, K. (2013). Vitamin C in human health and disease is still a mystery? An overview. J. nutr., 2(7):1-30.

Nwaogu L.A and Onyeze, G.O.C, (2010). Effect of spent engine oil on oxidative stress parameters of Telferia occidentalis leaves. Nigerian J. Biochem. Mol. Biol., 25(2):95-104.

Nwilo, P.C. and Badejo, O.T. (2005): Management of Oil spill dispersal along the Nigerian Coastal Areas. J. Envtal Mgt. 4;42-51.

Ogbo, M. E., Zibigha, M., and Odogu, G. (2009). The effect of crude oil on growth of the weed (paspalum scrobiculatum L.) - phytoremediation potential of the plant. African journal of Environmental Science and Technology Vol. 3 (9), pp 229-233

Omotoso OT, Adedire CO. (2007). Nutrient composition, mineral content and the solubility of the proteins of palm weevil, Rhynchophorus phoenicis f. (Coleoptera:Curculionidae).J. Zhejiang Univ. Sci. B.,8(5): 318-322.

Onwuka S. K. (2005). Cortical metal and crude protein levels of certain vegetables. Brain Talk communities 3: $15-23$

Onyeike, E.N., Ihugba, A.C. and George, c. (2003) Influence of heat processing on the nutrient composition of vegetable leaves consumed in Nigeria. Plant foods Hum. Nutr. 58:1-11

Oyinloye M.A. And Olamiju O.I. (2013) An Assessment Of The Physical Impact of Oil Spillage Using Gis And Remote Sensing Technologies: Empirical Evidence From Jesse Town, Delta State, Nigeria. British Journal of Arts and Social Sciences 12(2):235-252.

Pearson D. (1976). Chemical analyses of food. Churchhill, livingstone. 7:72- 73

Ziolkowskai L., Wyszkowskaii, H.J (2010).Reduction of nitrogen in humus region of plants by toxicants. Ecol. Chem. and Eng. 17:37-36. 